\title{
Handover Analysis Of Data Services In Wireless Distribution System (WDS) Using IEEE 802.11AC Standards In Telecommunication Laboratory Polines
}

\author{
Arya Pitaka ${ }^{1}$, Muhammad Anif. ${ }^{2}$, Agus Rochadi ${ }^{3}$ \\ 1,2,3 Electrical Engineering Department, Telecommunication Engineering D4 Study Program
}

\begin{abstract}
Problems with limited WLAN coverage areas often become a constraint when users access the Internet by migrating. This final project contains an analysis of the effect of handover on the quality of data service with Quality of Service (QoS) parameter that is throughput, delay, jitter and packet loss. The Wireless Local Area Network (WLAN) 802.11ac networking system in the Telecommunication Laboratory of Semarang State Polytechnic area that supports the handover feature is built with the Wireless Distribution System (WDS) technique that is configured with Service Set Identifier (SSID), the same password and channel and the placement of Access Point (AP) with overlapping coverage areas in one roaming domain. The tool used is Wireshark obtained the results of the test that is the average throughput value on the download service of $12,94 \mathrm{Mbps}$, the upload service of 11,22 Mbps and video streaming service of 3,66 Mbps. The average value of delay in the download service is $0,99 \mathrm{~ms}$, the upload service is $1,19 \mathrm{~ms}$ and the video streaming service is $3,07 \mathrm{~ms}$. The average value of jitter on the download service is $0,36 \mathrm{~ms}$, on the upload service of $0,35 \mathrm{~ms}$ and the video streaming service is $3,66 \mathrm{~ms}$. The average value of packet loss on the download service is $2,57 \%$, the upload service is $5,08 \%$ and the video streaming service is $7,03 \%$.
\end{abstract}

Index Terms - Handover, WLAN 802.11ac, Wireless Distribution System, Quality of Service

\section{INTRODUCTIO}

\section{N Background}

The development of technology in the field of telecommunication is very fast that is in Wireless Local Area Network (WLAN) network. This technology is very effective and efficient to facilitate the exchange of data in a popular local area environment among today's society with various needs to support mobility. In the environment Telecommunication Engineering Studies Program Politeknik Negeri Semarang WLAN network can be built to provide connectivity that supports mobile features that can be utilized by students and lecturers for teaching and learning activities. The area of Telecommunication Engineering Study Program consists of two buildings in two separate places, namely the West Telecommunication Laboratory building and the East Telecommunication Laboratory building.

Issues in the limited area of WLAN coverage often become a constraint when users access the Internet by migrating. The need for continuity of Internet access in the area of Western and Eastern Telecommunication Laboratory is needed to support user movement during teaching and learning activities. The switching of connections between wireless devices in the coverage area is known as handover.
In order to optimize the infrastructure of the Internet network that is built, it is made Wireless Local Area Network (WLAN) network with Wireless Distribution System (WDS) technique as a network link in the area of West and East Telecommunication Laboratory that supports handover feature.

\section{Purpose}

The purpose of this final project is to produce Wireless Local Area Network (WLAN) network system that supports handover feature and know the quality of data service when handover on WLAN network with Wireless Distribution System (WDS) technique using IEEE 802.11ac standard in Telecommunication Engineering Study Program Laboratory Semarang State Polytechnic.

\section{THEORETICAL BASIS}

\section{IEEE 802.3 Ethernet Technology}

802.3 is a standard that establishes various work characteristics on Ethernet especially regarding Local Area Network (LAN) technology (Soyinka, 2010). Ethernet is built on the principle of sharing cable media with other computers and is a broadcast protocol, meaning that data is sent to all computers on a single segment or one broadcast domain. 


\section{Wireless Local Area Network (WLAN)}

Wireless network is a network that uses wireless media in data transmission or information between hosts that use electromagnetic waves. WLANs use multiple hosts (users) connected to each other or connected to a wired network with the help of a device called Access Point (Towidjojo \& Eno, 2015). IEEE 802.11 is the standard for the application of WLAN functions in the Physical (PHY) layer and Media Access Control (MAC) sublayer of the OSI reference model (Soyinka, 2010).

\section{IEEE 802.11 Standards}

The IEEE established a working group aimed at standardizing known IEEE 802.11, which regulates Wireless Local Area Network (WLAN) technology, such as Radio Frquency (RF) used and data transmission speed (Towidjojo \& Eno, 2015).

\section{IEEE 802.11a Standards}

The IEEE 802.11a standard operates on the $5 \mathrm{GHz}$ Unlicensed National Information Infrastructure (UNII) frequency spectrum. IEEE 802.11a was released in 1999 using the Orthogonal Fequency Division Multiplexing (OFDM) modulation technique. The data transmission speed of IEEE 802.11a standard is 54 Mbps.

\section{IEEE 802.11b Standards}

The IEEE 802.11b standard was released in 1999. IEEE 802.11 b uses the $2.4 \mathrm{GHz}$ frequency spectrum, has a maximum data transmission speed of $11 \mathrm{Mbps}$ (Towidjojo \& Eno, 2015). IEEE 802.11b is the development of the Direct Sequence Spread Spectrum (DSSS) modulation scheme (Stallings, 2007)

\section{IEEE 802.11g Standards}

The $802.11 \mathrm{~g}$ standard is the standard issued in 2003 (Towidjojo \& Eno, 2015). This standard works on the $2.4 \mathrm{GHz}$ frequency spectrum of Industrial, Scientific, and Medical (ISM). IEEE 802.11g with data rates above $20 \mathrm{Mbps}$, up to a maximum of $54 \mathrm{Mbps}$ (Stallings, 2007).

\section{Standar IEEE 802.11n}

In 2009, IEEE issued an 802.11n standard that supports the use of $2.4 \mathrm{GHz}$ and $5 \mathrm{GHz}$ frequencies using Orthogonal Fequency Division Multiplexing (OFDM) techniques (Towidjojo \& Eno, 2015). IEEE 802.11n is able to achieve data transfer speeds of up to $600 \mathrm{Mbps}$.

\section{IEEE 802.11ac Standards}

The IEEE 802.11ac standard was released in 2013. In this standard a number of enhancements such as a wider channel are two new channel widths: $80 \mathrm{MHz}$ and $160 \mathrm{MHz}$, using a more complex modulation of 256-QAM (Quadrature Amplitude Modulation) that supports more bits data, beamforming technology, and increased data flow of up to eight spatial streams (Gast, 2013).

\section{Wireless LAN IEEE 802.11 Network Architecture}

Components of a Wireless Local Area Network (WLAN) network can be distinguished into logical components and physical components. Physical components include Wireless Medium, Wireless Station (STA), Distribution System, Access Point (Soyinka, 2010).

Wireless Distribution System is a wireless network system that makes interconnection between one Access Point with another Access Point by using wireless media (Towidjojo \& Eno, 2015).

\section{Handover On Wireless LAN}

Handover is a feature that allows wireless clients to move from one Access Point to another Access Point without losing its wireless connection (Towidjojo \& Eno, 2015). The wireless signal coverage area of an Access Point is called a cell. Handover or roaming features can be applied to ESS networks with WDS techniques.

\section{Handover or Roaming Domain}

Domain handover or roaming on a Wireless LAN network that is Access Point (AP) contained in the same broadcast domain and configured the same SSID is called on roaming the same domain.

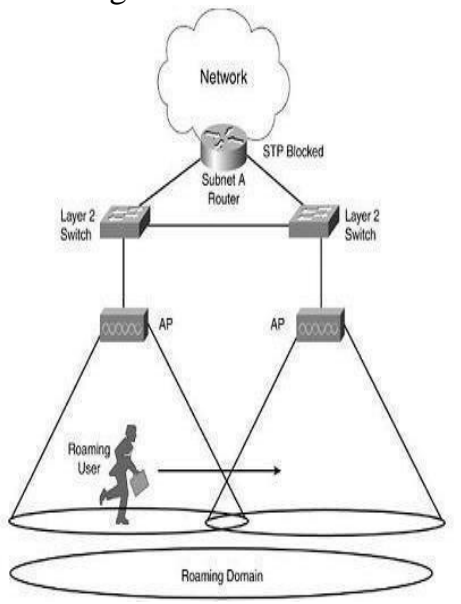

Figure 2.1 Roaming On Layer 2 (Source: Roshan \& Leary, 2003) 


\section{Handover Process}

The handover process is when the STA obtains a signal at the threshold point, and the STA makes better service switching to a new AP. In this handover process involves STA, old AP and new AP. Secra logical complete handover process there is step discovery and reauthentication (Mishra, Shin, \& Arbaugh, 2003).

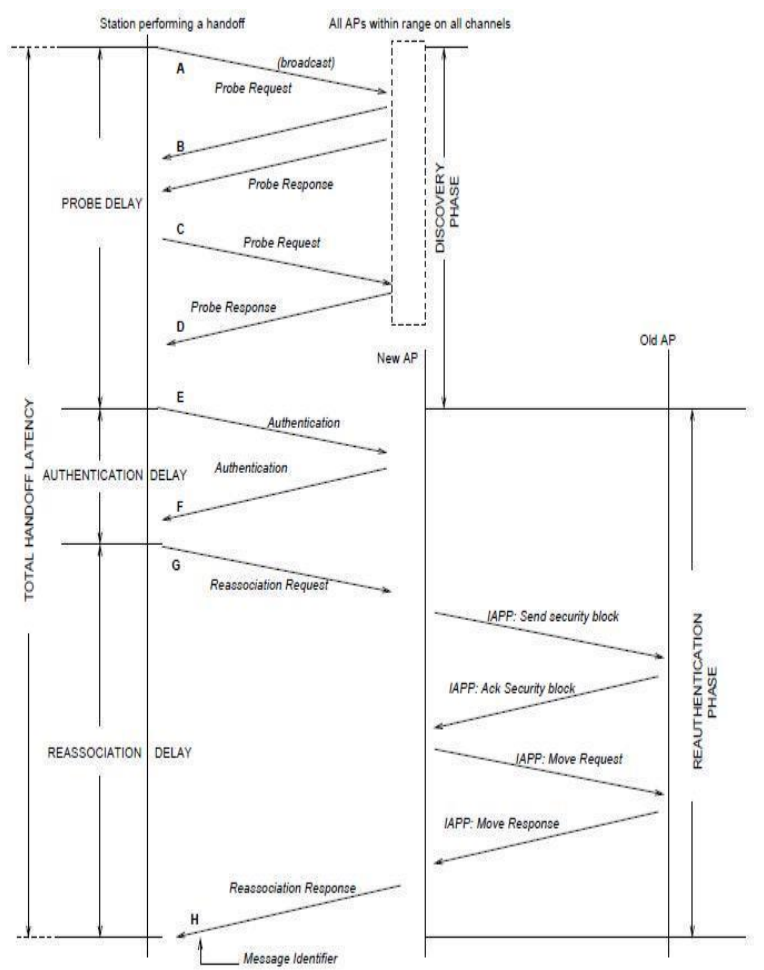

Figure 2.2 Proses Handover IEEE 802.11

(Source: Mishra, Shin, \& Arbaugh, 2003)

\section{Quality of Service (QoS)}

Quality of Service QoS refers to the network's ability to provide better service to certain network traffic through different technologies.

\section{Throughput}

Throughput is the effective data transfer rate measured in bps which is the total number of successful packet arrivals observed at the destination over a given time interval divided by the duration of the time interval.

Throughput calculation is done by equation (2.1) (Wulandari, 2016) as follows.

\section{Delay}

Delay is the time required to deliver a packet of data from the source (destination node) to destination (destination node) of the data packet (Firdaus et al, 2014). Delay calculation is done by equation (2.2) (Amalina et al, 2013) as follows. Delay recommendations according to ITU-G-114 are shown in Table 2.1.

Information:

tr $=$ Receipt time of the packet (ms)

ts $=$ Package delivery time $(\mathrm{ms})$

Table 2.1 ITU-G-114 Delay Recommendation (Source: Firdaus et al, 2014)

\begin{tabular}{|c|c|}
\hline Delay Value & Quality \\
\hline $0-150 \mathrm{~ms}$ & Good \\
\hline $150-400 \mathrm{~ms}$ & Enaugh, still acceptable \\
\hline$>400 \mathrm{~ms}$ & Poor, unacceptable \\
\hline
\end{tabular}

\section{Jitter}

Jitter is a variation of the delay or the difference from one delay to another by Firdaus et al (2014). Jitter's recommendation by TIPHON 1999 is shown in Table 2.2. Jitter calculation is done by equation (2.3) (Tao \& $\mathrm{Yu}, 2012$ ) as follows.

Information:

variation delay $=($ delay - average delay $) 2$

Table 2.2 Jitter Recommendation TIPHON 1999 (Source: Firdaus et al, 2014)

\begin{tabular}{|c|c|c|}
\hline Jitter Category & Jitter Value & Index \\
\hline Excellent & $0 \mathrm{~ms}$ & 4 \\
\hline Good & $0-75 \mathrm{~ms}$ & 3 \\
\hline Enaugh & $75-125 \mathrm{~ms}$ & 2 \\
\hline Poor & $125-225 \mathrm{~ms}$ & 1 \\
\hline
\end{tabular}

\section{Packet Loss}

Packet Loss is the number of packets lost during the transmission from source to destination (Firdaus et al, 2014). The calculation of Packet Loss is done with the following equation (2.4) (Wulandari, 2016).

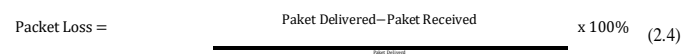


Table 2.3 Packet Loss Rekommendation (Sumber: TIPHON,1999)

\begin{tabular}{|c|c|}
\hline Packet Loss & Kualitas \\
\hline $0 \%$ & Excellent \\
\hline $3 \%$ & Good \\
\hline $15 \%$ & Enaugh \\
\hline $25 \%$ & Poor \\
\hline
\end{tabular}

\section{RESEARCH METHODS}

The research method used includes requirement analysis for literature study to get data that support in making and system design that done to ease in making system.

\section{Needs Analysis}

System needs analysis puprose to obtain information related to the needs of literature such as books, journals, research, scientific papers and articles and the needs of hardware and software to be used.

\section{System Design}

The built network topology is a WLAN network using IEEE 802.11ac standard with Extended Service Set (ESS) infrastructure mode with Wireless Distribution System (WDS) technique that supports handover feature in Western Telecommunication Laboratory and Eastern Telecommunication Laboratory Semarang State Polytechnic.

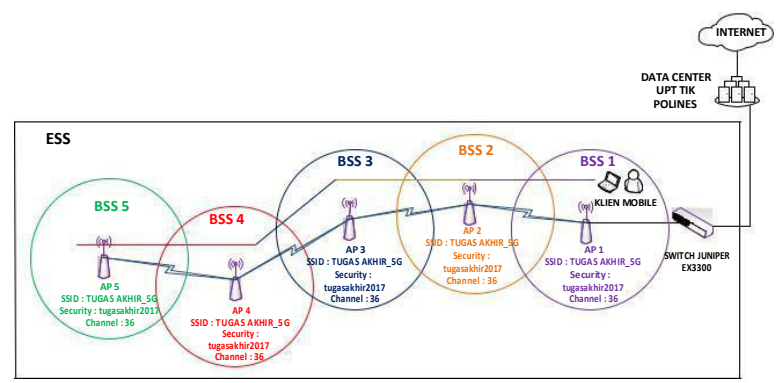

Figure 3.1 Network System

\section{Planning System Design and Creation}

Implementation is done by building WLAN network in Telecommunication Engineering Study Program which consists of device installation and device configuration. Configuration is done on WLAN network with Wireless Distribution System (WDS) technique that is configuration on accees point by arranging one Access Point with root mode and other Access Point in repeater mode with parameters such as
SSID, mode, band, channel width, channel and IP address which aims to build a Wireless Distribution System (WDS) network.

Testing of this handover process is done by determining four paths in performing AP service movement in each Basic Service Set (BSS) area. The movement of AP services across overlapping areas across the AP coverage area is shown in Table 3.1 ie first line from AP1 to AP2, on the second line from $\mathrm{AP} 2$ to AP3, third line from AP3 to AP4, and fourth line from AP4 to AP5. In Figure 3.2 shows the direction of the test path. The parameter used for the test is the normal moving client speed is $\pm 1.292 \mathrm{~m} /$ $s$ (LaPlante, 2006). The reference in the test corresponds to the path and parameters.

Table 3.1 Handover Testing Path

\begin{tabular}{|c|c|}
\hline Name of Path & Direction of Testing Path \\
\hline Path 1 & AP1 to AP2 \\
\hline Path 2 & AP2 to AP3 \\
\hline Path 3 & AP3 to AP4 \\
\hline Path 4 & AP4 to AP5 \\
\hline
\end{tabular}

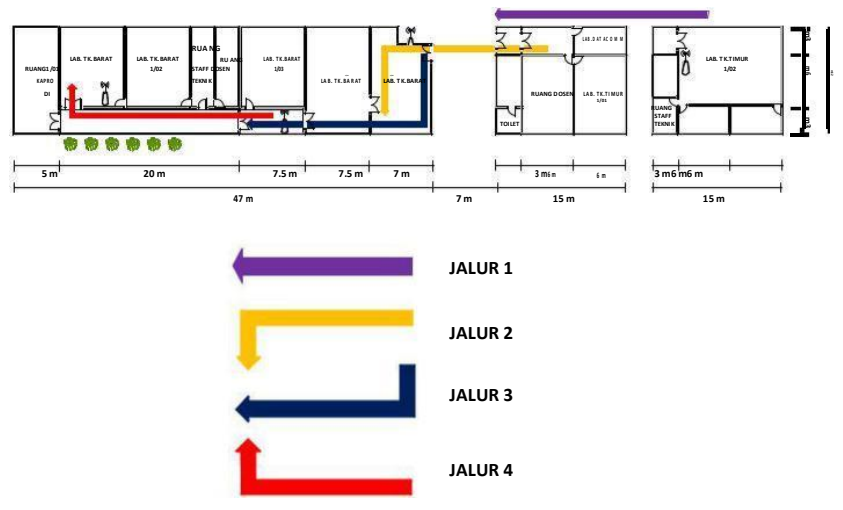

Figure 3.2 Handover Testing

\section{Path IV. RESULT AND DISCUSSION}

\section{Discussion and Analysis of Quality of Services (QoS) Data Services}

This section discusses Quality of Services (QoS) covering throughput, delay, jitter and packet loss from data services when handover testing is performed.

The average throughput data of each handover test path is shown in Table 4.1, the average end result of the data service throughput value in each of the following handover testing paths. 
Table 4.1 Average End of Throughput Value on the Handover Testing Path

\begin{tabular}{|c|c|c|c|}
\hline $\begin{array}{c}\text { Testing } \\
\text { Path }\end{array}$ & $\begin{array}{c}\text { Download } \\
\text { (Mbps) }\end{array}$ & $\begin{array}{c}\text { Upload } \\
\text { (Mbps) }\end{array}$ & $\begin{array}{c}\text { Streaming } \\
\text { Video } \\
\text { (Mbps) }\end{array}$ \\
\hline Path 1 & 16.0022 & 17.1598 & 4.0032 \\
\hline Path 2 & 14.452 & 11.5212 & 3.7842 \\
\hline Path 3 & 11.914 & 8.8864 & 3.4504 \\
\hline Path 4 & 9.4274 & 7.3122 & 3.4122 \\
\hline Average & 12.9489 & 11.2199 & 3.6625 \\
\hline
\end{tabular}

The average end-throughput value for the entire test path is on the download service of $12.9489 \mathrm{Mbps}$, on the upload service of $11.2199 \mathrm{Mbps}$ and on the video streaming service of $3.6625 \mathrm{Mbps}$.

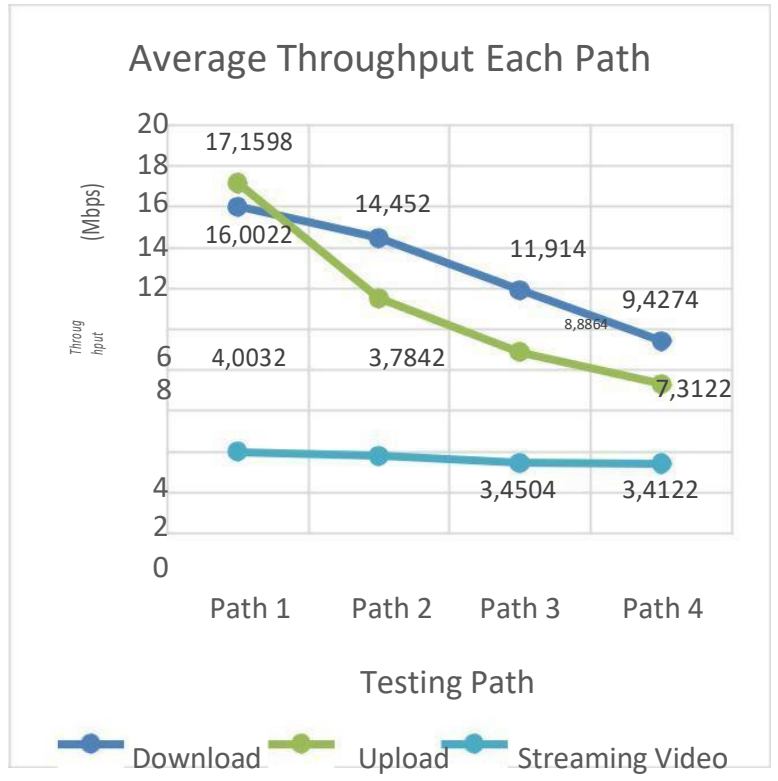

Figure 4.1 Average Throughput Chart Againts the Handover Testing Path

Based on Figure 4.1 the average throughput value of the download service, upload and streaming of videos is directly proportional to the handover testing path. The average value of throughput is decreased due to the bandwidth on AP2, AP3, AP4 and AP5 divided as a wireless distribution system so that throughput on test lines 2, 3 and 4 lower than the test path 1 . AP repeaters function to improve the quality of the signal is transmitted from each AP to extend the coverage area so that it can be accepted by the client and there is another effect that more AP repeaters are used, affecting the throughput value of the client according to the handling test path done.
The average delay data of each handover testing path is shown in Table 4:39, the average end result of the service data delay value in each of the handover test paths as follows.

Table 4.2 Average End of Delay Value on the Handover Testing Path

\begin{tabular}{|c|c|c|c|}
\hline $\begin{array}{c}\text { Testing } \\
\text { Path }\end{array}$ & $\begin{array}{c}\text { Download } \\
(\mathrm{ms})\end{array}$ & $\begin{array}{c}\text { Upload } \\
(\mathrm{ms})\end{array}$ & $\begin{array}{c}\text { Streaming } \\
\text { Video } \\
(\mathrm{ms})\end{array}$ \\
\hline Path 1 & 0.83315427 & 0.609565 & 2.746434171 \\
\hline Path 2 & 0.83926769 & 1.288597 & 2.890239671 \\
\hline Path 3 & 1.02344617 & 1.230064 & 3.317470625 \\
\hline Path 4 & 1.30033933 & 1.639187 & 3.350576586 \\
\hline Average & 0.99905186 & 1.191853 & 3.076180263 \\
\hline
\end{tabular}

The final average delay value for the entire test path is on the download service of $0.99905186 \mathrm{~ms}$, on the upload service of $1.125796425 \mathrm{~ms}$ and on the video streaming service of $3.076180263 \mathrm{~ms}$.

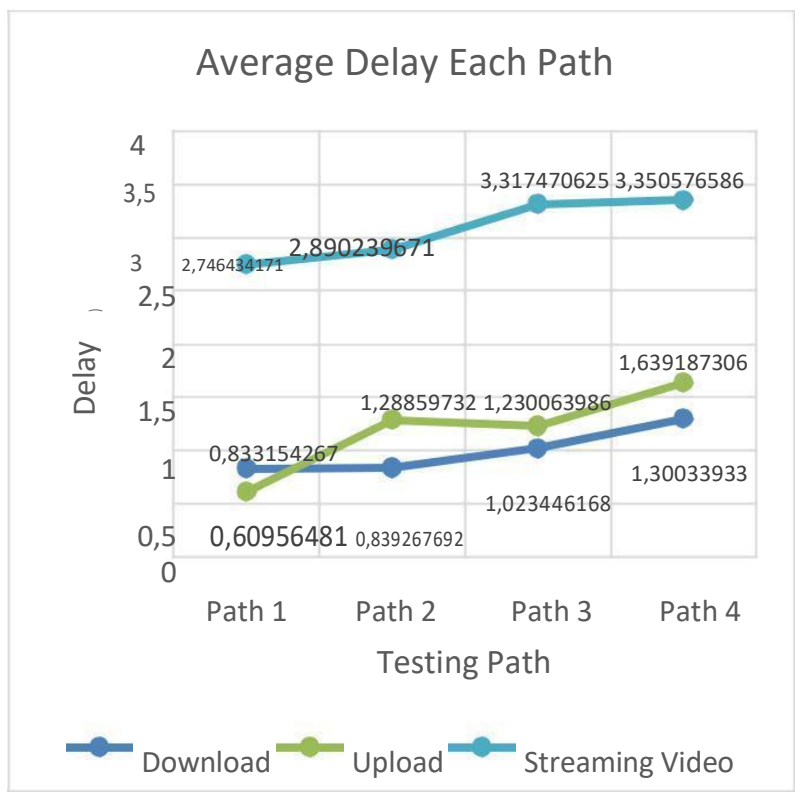

Figure 4.2 Average Delay Chart Againts the Handover Testing Path

The average value of delay in download, upload and streaming video services is inversely proportional to the average throughput value as shown in Figure 4.2. The value of the greater delay causes the value of throughput on the client to go down in accordance with the test path handover performed. On video streaming services have a higher average delay value compared to download and upload services because video 
streaming is a realtime service that is susceptible to delay in packet delivery from source to destination.

The average jitter data from each test of the handover test path shown in Table 4.3, shows the average end result of the data service jitter value on each of the handling test paths as follows.

Table 4.3 Average End of Jitter Value on the Handover Testing Path

\begin{tabular}{|c|c|c|c|}
\hline $\begin{array}{c}\text { Testing } \\
\text { Path }\end{array}$ & $\begin{array}{c}\text { Download } \\
(\mathrm{ms})\end{array}$ & $\begin{array}{c}\text { Upload } \\
(\mathrm{ms})\end{array}$ & $\begin{array}{c}\text { Streaming } \\
\text { Video } \\
(\mathrm{ms})\end{array}$ \\
\hline Path 1 & 0.2558706 & 0.090213 & 7.948984063 \\
\hline Path 2 & 0.2519643 & 0.259408 & 8.5342662 \\
\hline Path 3 & 0.2651323 & 0.47908 & 8.764606209 \\
\hline Path 4 & 0.6487912 & 0.569265 & 11.01065241 \\
\hline Average & 0.3554396 & 0.349492 & 9.064627221 \\
\hline
\end{tabular}

The end average jitter value for the entire test path is on the download service of $0.3554396 \mathrm{~ms}$, on the upload service of $0.349492 \mathrm{~ms}$ and on the video streaming service of $9.064627221 \mathrm{~ms}$.

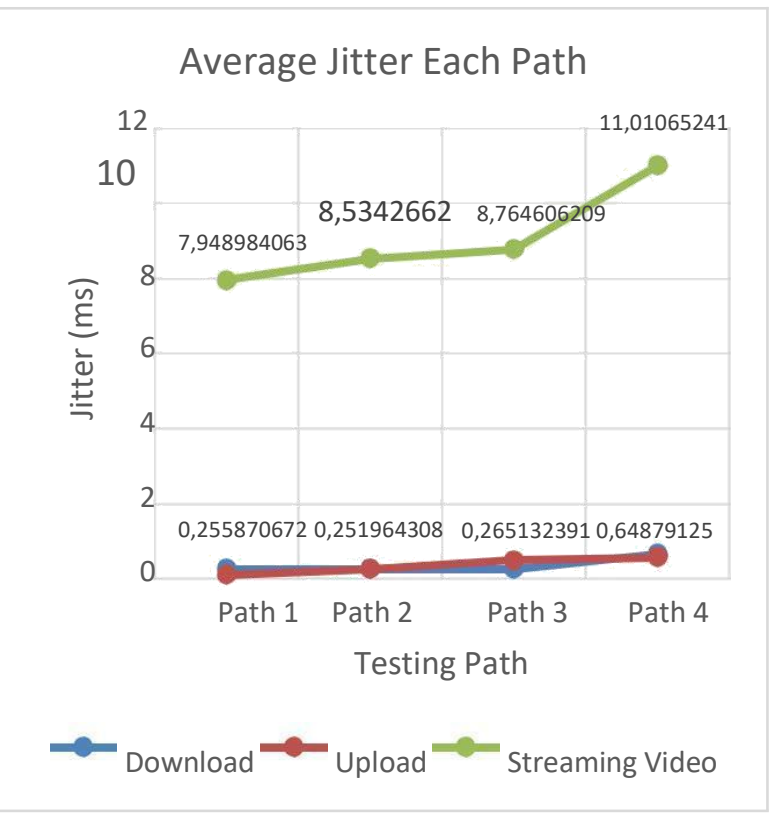

Figure 4.3 Average Jitter Chart Againts the Handover Testing Path

Based on Figure 4.3 the average value of jitter on the download service, uploading and streaming video is directly proportional to the average delay value. The value of the delay the greater the value of jitter on the greater the client in accordance with the test path handover performed. On video streaming services have a higher average delay value compared to download and upload services because video streaming is a realtime service that is susceptible to delay in packet delivery from source to destination.

The average packet loss data from each test of the handover test path shown in Table 4.4 shows the average end result of the packet loss data service value on each of the following handover testing paths.

Table 4.4 Average End of Packet Loss Value on the Handover Testing Path

\begin{tabular}{|c|c|c|c|}
\hline $\begin{array}{c}\text { Testing } \\
\text { Path }\end{array}$ & $\begin{array}{c}\text { Download } \\
(\%)\end{array}$ & $\begin{array}{c}\text { Upload } \\
(\%)\end{array}$ & $\begin{array}{c}\text { Streaming } \\
\text { Video } \\
(\%)\end{array}$ \\
\hline Path 1 & 1.69828108 & 4.058959 & 6.648866542 \\
\hline Path 2 & 2.12005109 & 5.054448 & 6.964478973 \\
\hline Path 3 & 2.54696528 & 4.556703 & 7.062163232 \\
\hline Path 4 & 3.92536597 & 6.688199 & 7.455128205 \\
\hline Average & 2.57266585 & 5.089577 & 7.032659238 \\
\hline
\end{tabular}

The end average packet loss value for the entire test path is $2.57266585 \%$ for download service, on upload service $5.089577 \%$ and on streaming video service $7.032659238 \%$.

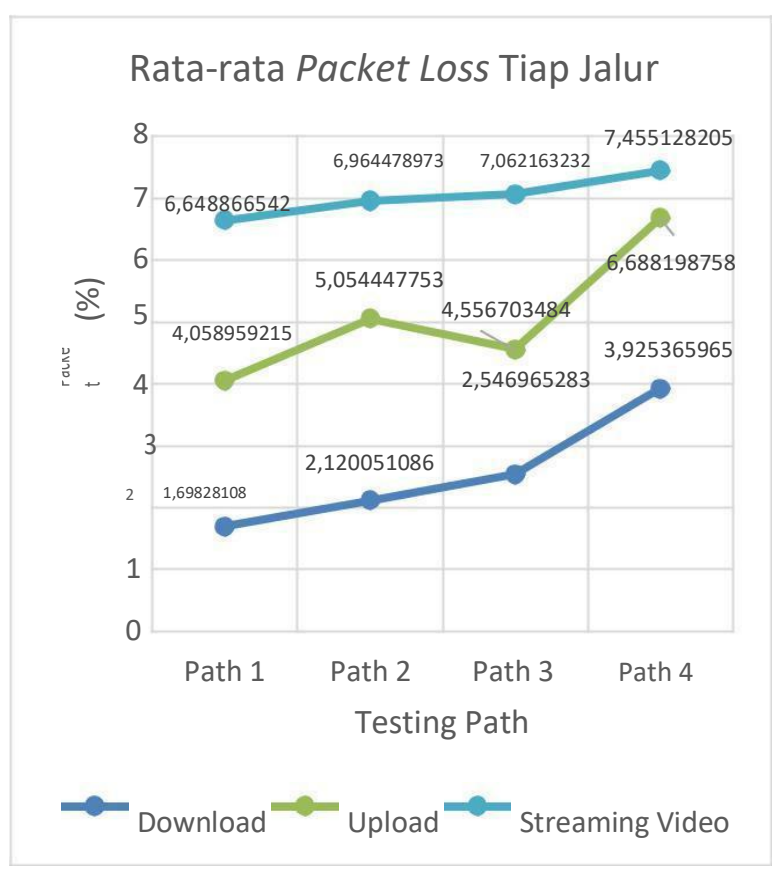

Figure 4.4 Packet Loss Charts Againts the Handover Testing Path

Based on Figure 4.4 the average value of packet loss on the download and upload services is relatively smaller compared to the video streaming service. The video 
streaming service is a realtime service that is vulnerable to packet delivery that is affected by delay and undelivered packets when AP service switches when handover testing is performed. The packet loss value is greater in accordance with the test path as shown in Figure 4.4.

\section{CONCLUSION}

Based on the discussion and analysis of data that has been done, can be drawn conclusion as follows.

1. Wireless Local Area Network (WLAN) networking systems that support handover features can be built with Wireless Distribution System (WDS) techniques configured with Service Set Identifier (SSID), same password and channel and placement of Access Point (AP) with coverage area which overlap in one roaming domain. The handover on the WLAN 802.11ac network occurs on clients with threshold RSSI values of -53 to $-70 \mathrm{dBm}$.

2. Quality of data service is indicated by Quality of Services (QoS) value during handover process as follows.

a. The downloaded service test result is the average throughput value of 12.94 Mbps, the average delay value of 0.99 $\mathrm{ms}$, the average jitter value of $0.36 \mathrm{~ms}$ and the average packet loss value of $2.57 \%$.

b. The test results of upload service is the average value of throughput of 11.22 Mbps, the average value of delay of 1.19 $\mathrm{ms}$, the average jitter value of $0.35 \mathrm{~ms}$ and the average packet loss of $5.08 \%$.

c. The result of video streaming service testing is the average value of throughput of $3.66 \mathrm{Mbps}$, the average delay value is $3.07 \mathrm{~ms}$, the average value of jitter is $9.06 \mathrm{~ms}$ and the average packet loss value is $7.03 \%$.

\section{REFFERENCES}

Amalina, E. N., Setijadi, E., \& Suwadi. (2013). Perbandingan Topologi WSN (Wireless Sensor Network) Untuk Sistem Pemantauan Jembatan. Prosiding Conference on SmartGreen Technology in Electrical and Information Systems, 85-90.

ETSI. (2017, Agustus 2). Telecommunications and Internet Protocol Harmonization Over Networks (TIPHON) General aspects of Quality of Service (QoS), TR 101329 V2.1.1
(1999-06). Retrieved from

http://www.etsi.org/deliver/etsi_tr/101300_1

01399/101329/02.01.01_60/tr_101329v0201

01p.pdf

Firdaus, Fahri, M., \& Nuraini, E. (2014). Dasar dan

Perancangan "Wireless ICT Networks" 3G-4G LTE$4 G$ Wimax-5G-Satelit. Yogyakarta: UII Press.

Gast, M. S. (2013). 802.11ac: A Survival Guide. Sebastopol, United States of America: O'Reilly Media, Inc.

Mishra, A., Shin, M., \& Arbaugh, W. (2003). An Empirical Analysis of the IEEEE 802.11 MAC Layer Handoff Process.

Roshan, P., \& Leary, J. (2003). 802.11 Wireless LAN Fundamentals. San Jose: Cisco Press. Sofana, I.

(2014). CISCO CCNA \& JARINGAN KOMPUTER. Bandung: Informatika.

Soyinka, W. (2010). Wireless Network Administration A Beginner's Guide. New York, United States of America: McGraw-Hill Companies.

Stallings, W. (2007). Komunikasi dan Jaringan Nirkabel (2 ed.). (G. Sagara, Ed., \& D. A. Sasongko, Trans.) Jakarta: Penerbit Erlangga.

Tao, L., \& Yu, F. (2012). Delay-Jitter aware slot assignment for Real-Time applications in wireless. Computer Communications, 19671982.

Towidjojo, R., \& Eno, M. (2015). Router Mikrotik : Implementasi Wireless LAN Indoor. Jakarta: Jasakom.

Wulandari, R. (2016). Analisis QoS (Quality of Service) Pada Jaringan Internet (Studi Kasus : UPT Loka Uji Teknik Penambangan Jampang Kulon-LIPI). Jurnal Teknik Informatika dan Sistem Informasi, Vol.2, No.2, 162-172. 
